\title{
Development of Choreography of the Zapin Dance in the City of Jambi
}

\author{
Martion ${ }^{1}$., Adjuoktoza Rovylendes²., Hasnah $^{3}$., and Asril. ${ }^{*}$ \\ 1, 2, 3, 4. Performing Arts Faculty, Institut Seni Indonesia Padangpanjang \\ * E-mail of corresponding author: asrilmuchtar2017@gmail.com
}

\begin{abstract}
The goal of this article is to discuss the development of the Zapin dance and Dana dance in the city of Jambi from the aspect of the changes in form of choreography. The Zapin dance and Dana dance are traditional dances with an Islamic cultural influence that have developed in the city of Jambi. These dances were brought by Arab traders several centuries ago when Islam was first introduced in Jambi, and served as a medium for Islamic proselytism or da'wah. The original dance was the Dana dance, which subsequently developed to become two separate dances, the Zapin dance and the Dana dance. The Zapin dance was developed by the Arab community from Kampung Manggis, while the Dana dance was developed by the mixed Arab and Jambi Malay community in Kota Seberang. The Zapin dance has subsequently undergone further developments to become a new, creative form of Zapin called Zapin kreasi, characterized by its attractive flying foot movements, which have made it popular among the young generation. The Dana dance, on the other hand, has been developed to include elements of the Malay Jambi culture, so that its movements, music, and costumes have been acculturated with local culture.
\end{abstract}

Keywords: development, Zapin dance, Dana dance, choreography

DOI: $10.7176 / \mathrm{ADS} / 83-10$

Publication date:July $31^{\text {st }} 2020$

\section{Introduction}

Zapin is a dance genre that has developed largely throughout the eastern region of Sumatra, especially in coastal towns and inland towns situated alongside rivers. Important centers for the growth and development of the Zapin dance are Medan and other nearby towns in North Sumatra, Palembang in South Sumatra, Pekanbaru and other small towns in Riau, and Jambi city in the Province of Jambi. The city of Medan, which is located on the east coast of Sumatra, is still one of the main centers of activity and creativity of Zapin dance and music. The three other cities mentioned - Palembang, Pekanbaru, and Jambi - are located in inland Sumatra, in areas traversed by rivers that are large enough for boats to pass through. The dance communities in these three cities continue to engage actively in Zapin dance and music activities. In addition to these large cities, there are numerous other smaller towns, both in coastal regions and near rivers, which have their own forms of Zapin dance and music.

The Zapin dance is identified as a dance form that exists in urban areas that are easily accessed through sea and river ports. This is related to the development of Islam in Sumatra, being first introduced to the island by Arab merchants who spread the religion while trading. Besides carrying out their activities in trading places along the coast, these Arab merchants also travelled to trading centers at the edge of large rivers. These trade centers subsequently developed into large towns and cities, one of which is Jambi. Many Arab merchants decided to stay permanently in these towns, forming their own Arab communities and marrying local women. The places where these Arab communities lived became centers of activity for the Zapin dance. According to Ja'far Rassuh, the Zapin dance, which in Jambi is also known as the Dana dance, first appeared together with the introduction of Islam in Jambi. The Islamic religion was spread by Arab merchants as they traded. They used the Zapin dance as a medium for proselytizing or da'wah in their efforts to develop the Islamic religion (Rassuh, 2000:267).

The kampungs, or districts, where Arab communities were established in Jambi are now known by the names Kampung Arab Melayu Kota Seberang dan Kampung Manggis. Both of these districts are centers of Zapin dance activities in the city of Jambi. It is interesting that in both places, the Zapin dance has developed with its own unique characteristics. In Kampung Arab Melayu Kota Seberang, the Zapin dance has been integrated with elements of the Malay Jambi culture, and is better known as the Dana dance. The elements of Malay culture that have become acculturated in the Dana dance can be seen in the dance steps, which are similar to the steps in the Malay Jambi martial art of silat. The Dana dance is supported by descendants of the original Malay Jambi community and people of mixed Malay Jambi and Arab descent. In the Kampung Manggis community, the Zapin dance has retained its characteristic foot movements, unique to the Zapin dance, and has become known as the Zapin Kampung Manggis dance. This dance is supported by descendants of the Arab community. 
The development of the Zapin dance in Jambi has followed the various social and cultural changes that have taken place in the community, in particular adapting to developments in the preferences of the supporting community. The existence of two versions of the Zapin dance in Jambi - namely the Zapin dance and the Dana dance - is the primary focus of this paper. The discussion centers on the forms of development of the Dana dance in Kampung Arab Melayu Kota Seberang, which has been acculturated with Malay culture, and the Zapin dance in Kampung Manggis, which has developed to become a new creative version of the Zapin dance - Zapin kreasi - that is popular among the young generation.

\section{Research Method}

This research uses a qualitative method which focuses on a case study about the development of the Zapin dance and Dana dance in the city of Jambi. The data collection focused on the development of aspects of choreography. In these choreographic developments, the movement, music, and costumes were also observed closely, to compare the two dances and the effect of the developments on the function of the two dances. To support the data collection, interviews were conducted with a number of informants and artists, especially those involved in the Zapin dance in Jambi. An additional study of various references related to the Zapin dance was also carried out to compare the developments that have taken place in the Zapin dance and Dana dance.

\section{Results and Discussion}

\subsection{Origins of the Zapin Dance and Dana Dance in Jambi}

There are two versions about the period when the Dana dance first appeared in Jambi. Ja'far Rassuh, an expert in the history of the Zapin and Dana dances, states: "During the first period, in the $13^{\text {th }}$ century, at the time of the Malay Jambi Kingdom, Arab merchants brought Islam to Jambi and used the Dana dance as a medium for Islamic proselytism or da'wah. The second period was during the reign of Orang Kayo Hitam (1500-1515). Orang Kayo Hitam nurtured and encouraged young Muslim preachers, equipping them with knowledge of self defence and teaching them the Dana dance. This dance was used as a social dance and at the same time served as a medium for gathering large numbers of people together to propagate Islam. The Dana dance was taught after evening prayers before or after training in the art of silat. It is believed that the Dana dance appeared during the reign of Orang Kayo Hitam.” (Rassuh, 2000: 267-268).

According to Rassuh, in Jambi, the Zapin dance is more commonly referred to as the Dana dance. He believes that the term Zapin itself did not appear in Jambi until the 1970s, from which time on it has been used primarily in the names of new dances, such as Zapin Rantau, Zapin Badrah, and Zapin Paklik. However, Rassuh is unsure when the name Dana was first used. From the time this dance first appeared in Jambi, it was known as the Dana dance, not the Zapin dance. It is likely that the word dana comes from the Arabic word din, which means religion. Dana originates from the accompanying music, as an outpouring of emotion and expression of the sound of the musical accompaniment for the dance (Ja'far Rassuh, 2000: 271-272).

To give a broader comparison of the names of the Dana dance and Zapin dance, here is a statement by the Indonesian choreographer and expert in the Zapin dance, Tom Ibnur:

"The name or title Zapin is used in eastern parts of North Sumatra (such as Deli, Serdang, Medan), as well as in Riau, South Sumatra, and Bengkulu. In Lampung, however, it is called Bedana and in Jambi it is known by the name Dana. Some people in South Sumatra and Bengkulu also use the same name as in Jambi. There is of course a specific reason for the different names given to this dance, especially in Jambi, because some communities of Arab descent still refer to it with the name Zapin. Those who use the name Dana, meanwhile, are perhaps members of communities that are an assimilation of Arabic and Malay Jambi descent. Others believe, however, that the word Dana was taken from the title of a song or melody used to accompany the dance (Ibnur, 2000: 63-64).

These statements by Rassuh and Ibnur are interesting and at the same time ambiguous, since the name Zapin is apparently more commonly used by communities of Arab descent living in the city of Jambi. It is not usual for these people to refer to this dance as the Dana dance. Meanwhile, those of mixed Arab and Malay Jambi descent refer to this dance as the Dana dance. People of Arab descent are descendants of the Arab traders who first brought the Dana dance to Jambi, and as such, they should be the ones who more commonly refer to this dance as the Dana dance. On the contrary, it would be more appropriate for people of mixed Arab and Malay descent to call the dance Zapin rather than Dana. 
The main difference between the Zapin dance and the Dana dance in Jambi is their supporting communities. The Zapin dance is supported by people of Arab descent, for example in the Zapin Kampung Manggis dance, while the Dana dance is supported by people of Malay Jambi descent and mixed Arab Malay Jambi descent based in the Arab Melayu Kota Seberang district of Jambi. Hence, the Zapin dance and Dana dance essentially belong to the same family or group. The difference in name is not a cause for serious debate between the different communities or in the broader Jambi community. There is, however, a tendency for the name Zapin to be perceived as a dance that has been developed into a more modern, creative form from the original dance.

\subsection{Development of the Zapin Dance}

The discussion about the development of the Zapin dance and Dana dance focuses on aspects of choreography and is strengthened by looking at aspects of music and costume. The Zapin dance has developed to become a new creative form known as Zapin kreasi, characterized by its flying foot movements and attractive nature, while the Dana dance has also developed to become a new creative form - Dana kreasi-characterized by its stamping foot movements and acculturation with the Malay Jambi culture.

\subsubsection{Structure of The Zapin Dance and Dana Dance}

The main characteristics of the movements of the Zapin dance and Dana dance are the foot movements. According to Ibnur, the name Zapin originates from the word al-zafn, which means foot movements. The hand movements occur as a natural effect of the movement of the body resulting from the movement of the feet. The floor patterns and foot movements are discussed more often than other body movements. For example, in the movements titi batang, loncat belanak, tegagau, selimpat empat, selimpat delapan, sut patin, gencat, tahto, tahtim, bujur, serong, pinang kotai, alif, pusing tengah, pecah delapan, ayam patah, 89ngina89aman, catuk, geliat, mata 89ngina, and so on. Hand movements, meanwhile, provide a guideline for hand forms or motifs such as sembah, ngempu and genggam baro, and other hand movements such as: bejulat, bekayuh, lenggang sebelah, tepuk, and so on. (Ibnur, 2000: 65).

The structure of a performance of Zapin dance generally consists of three sections: the introduction, including the sembah (to greet or pay homage), the main part of the dance with various movements, and the tahtim or tahto as the ending (Takari and Dewi, 2008: 162). The structure of a Zapin dance performance that Takari and Dewi refer to also applies to the Dana dance and Zapin dance in Jambi, irrespective of their different names. For example, in the Zapin dance in Jambi, the final section is called the tahtim runduk penutup movement, while in the Dana dance it is known as the sembah penutup movement.

Movements in the Dana dance, according to Rassuh (2000: 272-273), were originally quite simple, including steps forwards, backwards, left and right, and turning around. The steps used were similar to steps used in the Malay Jambi martial art, silat. These dance movements were performed over and over, without any particular limitations of tempo or time, but depending strongly on the accompanying music. If the musical accompaniment stopped, the dancers would also spontaneously stop dancing. Before starting to dance, the dancers would greet the musicians as a sign that they were ready to begin dancing. The movements in the dance would be in the form of: (1) Dancing on one spot, either face to face, or all facing in the same direction, towards or away from the audience; (2) Moving forward together in the direction of the audience, or back to their original places; (3) Turning around at the end of each forward or backward movement; (4) Standing face to face and taking turns to move, swapping places, then returning to their original place with a backwards movement. These same movements were also found in the Zapin dance in Kampung Manggis, the only difference being that the dancers would alternate between standing face to face with each other and standing side by side.

In subsequent developments, however, the Dana dance and Zapin dance began to include movements that were sourced from movements of the mullet fish, movements of a person walking along a fallen tree trunk/branch, movements mimicking descending and ascending, and other newly developed movements. According to Tom Ibnur, the structure of movements in the Zapin dance and Dana dance is generally the same, but there are certain differences in the names of the movements, the ways they are produced, and the style in which they are performed. Movements in the Dana dance include: lenggang sebelah, duduk dan sembah, ragam titi batang, ragam selimpat empat, ragam selimpat delapan, ragam syarah, sembah penutup, and lenggang tegagau. Movements in the Zapin dance include: julus dan runduk salam, qiyam dan langkah pembuka, jalan pembuka, ragam balik berputar, ragam silang menyilang, ragam jenjit/jinjit, ragam sayap tengah, and tahtim runduk penutup (Ibnur, 2000: 71; See also Rovylendes, 2010). 
Some of the movements in these two dances are performed over and over again, in between the other movements. For example, the movement loncat belanak in the Dana dance is performed in between the ragam titi batang, ragam selimpat empat, ragam selimpat delapan, and ragam syarah movements. Therefore, the loncat belanak movement will appear or be performed three times, in between these other movements, in every performance of the Dana dance. This is also the case with the jalan pembuka movement in the Zapin dance, which appears and is performed four times, in between the qiyam dan langkah buka, ragam balik berputar, ragam silang menyilang, ragam jenjit, and ragam sayap tengah movements.

The table below shows a comparison of the movements in the Zapin Kampung Manggis dance and the Dana dance.

\begin{tabular}{|c|c|c|c|}
\hline \multirow{14}{*}{$\begin{array}{l}\text { Movement } \\
\text { variants }\end{array}$} & Dana Dance & $\begin{array}{c}\text { Zapin Kampung } \\
\text { Manggis Dance }\end{array}$ & Information \\
\hline & Lenggang sebelah & - & $\begin{array}{l}\text { This movement is not } \\
\text { present in the Zapin } \\
\text { Kampung Manggis dance }\end{array}$ \\
\hline & $\begin{array}{l}\text { Duduk dan sembah } \\
\text { salam }\end{array}$ & Julus dan runduk salam & $\begin{array}{l}\text { Julus dan runduk are } \\
\text { movements performed while } \\
\text { looking down in a seated } \\
\text { position }\end{array}$ \\
\hline & Langkah buka & Qiyam dan langkah buka & $\begin{array}{l}\text { Qiyam is an upright/standing } \\
\text { position }\end{array}$ \\
\hline & - & Jalan pembuka & $\begin{array}{l}\text { This movement is not } \\
\text { present in the Dana dance }\end{array}$ \\
\hline & $\begin{array}{l}\text { Ragam titi batang } \\
\text { (walking along a tree } \\
\text { trunk) }\end{array}$ & Ragam balik berputar & $\begin{array}{l}\text { Titi batang is a movement } \\
\text { like walking along a fallen } \\
\text { tree trunk }\end{array}$ \\
\hline & Loncat belanak & Jalan pembuka & - \\
\hline & Ragam selimpat empat & Ragam silang menyilang & $\begin{array}{l}\text { Selimpat is a movement } \\
\text { mimicking descending and } \\
\text { ascending }\end{array}$ \\
\hline & Loncat belanak & Jalan pembuka & - \\
\hline & $\begin{array}{l}\text { Ragam selimpat } \\
\text { delapan }\end{array}$ & Ragam jenjit & $\begin{array}{l}\text { Jenjit is a movement in } \\
\text { which the dancer stands on } \\
\text { the toes, with the sole of the } \\
\text { foot and heel lifted }\end{array}$ \\
\hline & Loncat belanak & Jalan pembuka & - \\
\hline & Ragam syarah & Ragam sayap tengah & $\begin{array}{l}\text { Syarah in the Zapin dance is } \\
\text { performed separately }\end{array}$ \\
\hline & Sembah penutup & Tahtim runduk penutup & - \\
\hline & Lenggang tegagau & Not present & $\begin{array}{l}\text { Lenggang tegagau is a } \\
\text { movement showing surprise }\end{array}$ \\
\hline
\end{tabular}

From the comparison of different types of movements above, it can be seen that the Zapin dance and Dana dance have similar dance structures in the sense that they both begin with an opening greeting and end with a closing greeting. All the variants of dance movement begin with the same sequence of movements. The differences between the two dances are primarily at the beginning and end of the dance. The Dana dance starts with the a movement called lenggang sebelah, which is a dance movement performed while entering the stage, and ends with a movement called lenggang tegagau to leave the stage. Meanwhile, the Zapin Kampung Manggis dance begins directly with the julus or runduk salam movement (giving a greeting by bowing the head), a movement in which the dancers sit in one place, together in pairs. The dancer on the right sits with the left knee touching the floor, resting the weight of the body on the heel of the right foot, and the other dancer sits the opposite way round. The Zapin dance ends with the movement tahtim or runduk penutup, performed in one place.

Another difference between the two dances is the way the dancers dance together in pairs. In the Zapin Kampung Manggis dance, 'in pairs' means side by side, although in certain movements the dancers face each other. In the Dana dance, however, 'in pairs' means in a face-to-face position, and in all the dance movements the dancers face each other. The only exception is the loncat belanak movement, in which the pairs of dancers perform the movement side by side (Ibnur, 2000: 72). 
In every performance of the Dana dance and Zapin dance, there is a special section known as syarah which is always present. In the Dana dance, syarah is integrated into the Dana dance. Syarah is performed to make the atmosphere more lively. One of the main characteristics of syarah is its musical rhythms and faster tempo. It serves as the climax of the Dana dance, bringing excitement to the performance. In the Zapin Kampung Manggis dance, however, syarah is a 'dance' in itself, separate from the main Zapin dance. Usually, syarah is performed at the peak or climax of a celebration, and all the guests or members of the audience dance together in time with the music, with their own 'free-style' movements. In a Zapin performance, syarah provides a 'space' for anyone present, who enjoys and knows how to dance the Zapin dance, to participate in the dancing. Syarah is characterized by its fast tempo and joyful mood.

According to Rimala Isma, an activist in Jambi dance and culture: "The character of the movements in the Dana dance and Zapin dance is actually quite different. The movements in the Dana dance, especially the foot movements, tend to be performed while stamping or pounding the feet, since many movements have been adopted from the Malay Jambi martial art, silat, while the foot movements in the Zapin dance tend more towards flying or floating movements, so the dancers appear more attractive and graceful." (Rimala Isma, interview, September 2019 in Jambi).

The different character of the movements in the two dance genres is strongly influenced by subsequent developments to the original form. The Zapin dance has been developed more to become a new form of Zapin kreasi. Choreographers and members of the young generation in the city of Jambi prefer to dance the Zapin dance because of the character of the swaying, flying foot movements. This attractive element is highlighted in every performance of a Zapin kreasi dance. Young people can develop Zapin kreasi dances for events such as school inaugurations, Zapin dance festivals, and as pure entertainment. Zapin kreasi provides a 'space' for young choreographers and young people in Jambi to explore and create more widely without being tightly bound to the rules of Zapin dance movements. They delight in the unique flying foot movements of the Zapin dance and are able to present more attractive movements through the movement of the feet. Likewise, they create new floor patterns and formations that are more aesthetically pleasing.

The development of Zapin kreasi dances has been carried out by numerous art studios and dance groups that are oriented towards new choreography. Rimala Isma is a dance activist in Jambi who also choreographs new dance creations based on the Zapin dance and other traditional dances. There are several art studios in the city of Jambi that perform new creations of the Zapin dance as well as other dance creations. These new creations have spread to various places, such as Pelayangan, Telanai Pura, and Alam Barajo. The district of Alam Barajo is one area with a large number of creative artists and dance studios specializing in creative dance (Department of Culture and Tourism, Province of Jambi, 2017). The Zapin dance in the city of Jambi today is no longer centered in Kampung Manggis but has also spread to other areas of the city.

These developments of the Zapin dance by choreographers are not only based on the Zapin dance alone, but also the Dana dance and a combination of the two dances. These choreographers have various reasons and goals. For example, if a Zapin dance is to be used for a festival and entertainment, the choreographer usually prefers to develop a new Zapin dance based on the movements of the original Zapin dance. On the other hand, choreographers who wish to develop the Zapin dance by creating a new dance with elements of Malay culture, prefer to develop movements from the Dana dance.

These new developments of the Zapin dance are not only focused on aspects of choreography but also the dancers or performers. According to the traditional concept of the Zapin dance and Dana dance, dancers in both cases must be male. However, in the development of Zapin kreasi dances, female dancers are also included, and are paired together with male dancers. This is now possible because the Zapin dance no longer functions as a medium for disseminating and proselytizing Islam but is used more as entertainment, or in competitions and festivals. This change in function of the Zapin dance means that the form of new Zapin kreasi dances places more priority on its aesthetic aspects, ensuring it is both pleasant to perform and attractive to watch.

Developments in science, communication, and opportunities for artistic interaction have led to changes in social behaviour. This has also affected the existence of the Dana and Zapin dances. The Dana dance and Zapin dance are now performed by female dancers, either exclusively or in pairs with male dancers. Rassuh states that the Dana dance is no longer performed in pairs but has been adapted to suit the wishes of the choreographer, even though it still continues to use a vocabulary of movements from the traditional Dana dance (Rassuh, 2000:273). The 
developments that have taken place have given a new function to the Dana dance and Zapin dance, namely as dances for performance.

The inclusion of female dancers in the Zapin dance in other parts of Indonesia has also become commonplace. In Medan, North Sumatra, for instance, the Zapin dance has been performed by female dancers since the 1960s, and this became increasingly common during the 1970s. There are even some Zapin dance groups in which all the dancers are female, such as the Petumbukan Zapin dance group, the Sri Indra Ratu dance group, and the dance group of Jose Rizal Firdaus. (Jose Rizal Firdaus, 2000:250-251). The Zapin dances that use only female dancers are Zapin kreasi dances. The choreographers of these dances create new Zapin dances in aspects of the choreography, the dancers, and also the musical accompaniment, while at the same time taking into careful consideration the aesthetic element.

\subsubsection{Musical Accompaniment for the Zapin Dance and Dana Dance}

Zapin essentially contains two different artistic media, namely Zapin dance and Zapin music. In a dance performance, the Zapin dance and music form a single entity; Zapin music is the music for the Zapin dance. Without the Zapin music the Zapin dance cannot be performed. As Said Parman explains, Zapin music is the intimate accompaniment for the Zapin dance (Parman, 2000:196). However, Zapin music can also be performed independently, without the dance.

The Zapin dance sometimes uses special musical instruments, as well as the more common instruments such as marwas (a small, double-headed drum), violin, harmonium, and voice. For instance, in Zapin hajjir marawis, a kind of Arabic Zapin, the instruments used are only marwas, hajjir, madruf, and the human voice. Meanwhile, in Zapin gambus, the instruments used are marwas, dumbuk (a drum shaped like a wine glass), violin, harmonium, tambourine, and voice. Many of the songs used are taken from Middle Eastern song repertoire and have Arabic texts or verse. Zapin Kampung Manggis uses this kind of music to accompany the dance.

The musical accompaniment for the Dana dance is different, the principle difference being in the songs and the texts or verse. The songs used in the musical accompaniment for the Dana dance are taken from Malay melodies with Middle Eastern influences or local Malay songs, but the texts and verse are sung in the Malay language. Originally, the music for the Dana dance was very simple, and the only instrument used was the tor, a kind of tambourine. Fastened around the edge of the tor are a number of metal plates which can produce a sound. In subsequent developments, other instruments such as the gendang melayu, marwas, violin, and accordion also started to be included. In other cases, the musical accompaniment may be combined with rebana, kecapi, and tetawak instruments. The songs used to accompany the Dana dance are quite varied, and include songs such as Anak Ayam, Dendang Beranyut, Cerai Kasih, and Apo Dayo. The melodies used to accompany the Dana dance are a combination of Malay music and music with 'desert' (Middle Eastern) rhythms (Rassuh, 2000:275).

Zapin music is commonly referred to as music with a traditional nuance because all the musical instruments used are made from natural materials such as the wood of jackfruit, breadfruit, and laban trees. The musical instruments in a Zapin ensemble consist of a gambus, four marwas, and several other instruments, depending on the particular genre or ensemble. Zapin music places a great deal of importance on the central melodic line. The beating sound of the marwas drum is not absolutely essential, as the singers and musicians can hear the unique rhythms in their heads. Zapin rhythms can also be played on a different kind of drum, called gebano (a Malay drum) by a single musician, who plays the pulsating, rhythmic patterns of Zapin music. The melodies of Zapin music are mostly played on the gambus but can also be played by the violin, accordion, or harmonium, to accompany the singing.

In addition to playing the melodic line in its entirety, Zapin music also provides something different at the beginning and end of the dance. The entrance to the dance, with the greeting or homage of the dancers, is preceded by an interlude, in which the duration of each bar of the melody depends on the distance the dancers must cover to enter or leave the arena, lasting as long as the marwas is not struck. In a dance music ensemble, no fewer than four marwas should be used, and all four of the musicians play different interlocking rhythmic patterns.

\subsubsection{Dance Costumes}

The costumes used for the Zapin Kampung Manggis dance and Dana dance in Jambi do not follow any strict rules or regulations. This is because of the different environments or situations where the Dana dance is found. The occasion on which the dance is performed is also a determining factor. Nevertheless, in general, the costumes worn are traditional. Female dancers wear a long, loose dress known as baju kurung, and long trousers, covered with a 
piece of songket or batik cloth. They also wear a shawl draped around the shoulders, fastened around the waist, or covering the head. The female dancers' costumes are usually red, yellow, or green. The male dancers wear a longsleeved round-necked shirt (baju teluk belanga) and trousers, with a piece of knee-length songket or batik material wrapped round the waist, and a black, cone shaped kopiah or songkok skull cap on the head. The costumes of the male dancers are usually yellow, green or blue. There have been very few developments to the dance costumes because choreographers of the Zapin and Dana dances take into careful consideration the aspect of Islamic norms and values, as well as Jambi customs and traditions. Any developments made to the dance costumes need to consider first and foremost how the dancers will be able to move freely and smoothly, especially in the flying, attractive, graceful foot movements.

\section{Conclusion}

The Zapin dance in the city of Jambi has two versions, namely the Dana dance and the Zapin dance. The Dana dance was developed by the Arab Malay community with the strongest base being the Arab Melayu Kota Seberang district of Jambi. The developments of this dance include combining elements of the Dana dance with Malay Jambi culture. The main characteristic of the Dana dance is the stomping foot movements. The Dana dance is considered to be the earliest form of Zapin dance in the city of Jambi. The Zapin dance, meanwhile, was developed by the Arab community based in Kampung Manggis, with its characteristic flying foot movements. Both of these dances have developed with their own unique styles. From the aspect of choreography, the Zapin dance has developed into new creative forms, known as Zapin kreasi, which are popular among young people and present more attractive, flying foot movements that are aesthetically more appealing. These new creations of the Zapin dance are performed widely in contexts of entertainment, competitions, and festivals. The Dana dance has also developed in a similar fashion, with new creative versions, or Dana kreasi, but these new dances are not as popular as the new creations of Zapin. The numerous art studios and choreographers that exist throughout the city of Jambi prefer to develop the new creative form of Zapin kreasi.

\section{References:}

Dinas Kebudayaan dan Pariwisata Provinsi Jambi. (2017), Inventarisasi Seni Budaya Program Pengelolaan Keragaman Budaya Tahun 2017. Jambi: Dinas Kebudayaan dan Pariwisata Provinsi Jambi.

Firdaus, Jose Rizal. (2000), “Tari Zapin dan Perkembangannya di Deli Serdang,” in Mohd Anis Md Nor ed, Zapin Melayu di Nusantara. Johor: Yayasan Warisan Johor.

Ibnur, Tom. (2000), "Dana: Tari Pergaulan Bernafaskan Islam di Jambi,” in Mohd Anis Md Nor ed, Zapin Melayu di Nusantara. Johor: Yayasan Warisan Johor.

Parman, Said. (2000), “Zapin Riau: Tinjauan Koreografi dan Ensambel Perkusi,” in Mohd Anis Md Nor ed, Zapin Melayu di Nusantara. Johor: Yayasan Warisan Johor.

Rassuh, Ja'far. (2000), “Sejarah Perkembangan Tari Dana di Propinsi Jambi,” in Mohd Anis Md Nor ed, Zapin Melayu di Nusantara. Johor: Yayasan Warisan Johor.

Rovylendes, Adjuoktoza. (2010) “Tari Zapin Kampung Manggis Jambi," textbook. Padangpanjang: ISI Padangpanjang.

Takari, Muhammad., and Heristina Dewi. (2008), Budaya Musik dan Tari Melayu Sumatra Utara, Medan: USU Press.

Informant:

Rimala Isma, 55 years old, Jambi dance and culture activist, interviewed in September 2019 in Jambi. 